\title{
Environmental stress in the northern Tethys during the Paleogene: a review of foraminiferal and geochemical records from the Polish Outer Carpathians
}

\author{
Barbara OLSZEWSKA ${ }^{1}$ and Andrzej SZYDŁO ${ }^{1, *}$
}

1 Polish Geological Institute - National Research Institute, Carpathian Branch, Skrzatów 1, 31-560 Kraków, Poland

Olszewska, B., Szydło, A., 2017. Environmental stress in the northern Tethys during the Paleogene: a review of foraminiferal and geochemical records from the Polish Outer Carpathians. Geological Quarterly, 61 (3): 682-695, doi: 10.7306/gq.1369

\begin{abstract}
During the Paleogene, the area of the northern Tethys was controlled by a turbidity system stimulated by diastrophic and geodynamic processes. These factors contributed to the dispersion and rapid oxygenation of organic debris. Its accumulation was a consequence of stagnant bottom water conditions that periodically occurred in the basin. In these periods, intense decomposition intensified by hydrothermal and diagenetic processes was associated with oxygen consumption and the release of greenhouse gases, which led to hypoxia and acidification. These phenomena intensified by thermal and density stratification had a major impact on the structure, evolution and distribution of biota. Stress associated with rapidly changing conditions induced by sedimentary process and upwelling resulted in the dominance of forms that colonized most sediments (Glomospira, Ammodiscus, Recurvoides, Rzehakina) and surface waters (Guembelitria, Chiloguembelina, Globanomalina, Globigerina, Cassigerinella, Catapsydrax). At the time, foraminifera were limited to low-diversified eutrophic assemblages or were mainly replaced by siliceous phytoplankton (radiolarians and diatoms). Geochemical data confirm that environmental crises in the Paleogene basin took place under changing thermal conditions that reflect global events (KTBE, PTME, EEOC and TTE). Thermal stress favouring the formation of certain minerals or rocks occasionally occurred during the Paleocene to Eocene (siderite, phosphates) and dominated in the Early Oligocene (silica).
\end{abstract}

Key words: Outer Carpathians, Poland, Paleogene, foraminifera, geochemistry.

\section{INTRODUCTION}

The Paleogene was a period of major changes in ocean circulation and global climate, induced by reorganization of tectonic plates, accompanied by intense volcanic and diastrophic activities and sea level fluctuations (Haq et al., 1988; Vogt, 1989). These external factors influenced the accumulation and preservation of organic debris in marine deposits (Calvert and Pederson, 1992). Its decomposition associated with oxygen consumption led to anoxia. The spread of these conditions in the basin depended not only on the water temperature and salinity, but also on the intensity of hydrothermal and diagenetic processes (Brener, 1984; Tucker, 1991; Katz et al., 2001). These processes associated with the release of volcanic and biogenic gases and fluids $\left(\mathrm{CO}_{2}, \mathrm{NH}_{3}\right.$ and $\left.\mathrm{SiO}_{2}\right)$ also favoured the formation of minerals (phosphorite, siderite) which contributed to calcium utilization and acidification (Zachos et al., 2005; Williams et al., 2017).

Through most of the Paleogene, oxidative and geochemical stress took place under warm "greenhouse" climatic conditions (Zachos et al., 2001; Pujalte et al., 2009). The warming trend

\footnotetext{
* Corresponding author, e-mail: andrzej.szydlo@pgi.gov.pl Received: March 21, 2017; accepted: April, 18, 2017; first published online: July 28,2017
}

started at the Maastrichtian-Paleocene transition and intensified at the Paleocene-Eocene Thermal Maximum (PETM), culminating in the Early Eocene (EECO) (Fig. 1). After this climatic optimum, short-term warming events occurred until the end of the Eocene (Bohaty and Zachos, 2003; Röhl et al., 2005; Thomas et al., 2006; Luciani et al., 2016). Futher climate change occurred close the Eocene/Oligocene boundary. At that time the closure of the Tethys seaway (Terminal Tethyan Event - TTE) and limited marine connections between the Indian Ocean and the Atlantic led to perturbations in the ocean circulation and sea level fluctuations which resulted in a cooling effect (Barron and Baldauf, 1989; Miller et al., 2009). However, this trend was interrupted by the warming episode in the Late Oligocene $26 \mathrm{Ma}$ (Miller et al., 1987; Zachos et al., 2001; Villa and Persico, 2006; Pekar et al., 2006).

Under these climate conditions, environmental stress affected the number and structure of the biota to a variable degree. It usually created opportunities for the establishment and survival of new forms and favoured opportunistic species of animals or plants that are adapted to exploit newly available habitats or resources and can be recognized as indicators of eutrophic environments (Levinton, 1970; Dimichele et al., 1987; Frezza et al., 2005; Alegret et al., 2012). Foraminifera include taxa that tolerate a wide range of environmental conditions. The distribution of these organisms is determined by oxygen and food availabilities (Gooday, 1990; Kuhnt et al., 1996; Stigter et al., 1998; Heinz et al., 2001; Alegret and Thomas, 2009, 2013; Arreguín-Rodríguez et al., 2013). The extinction of specialized forms with massive 


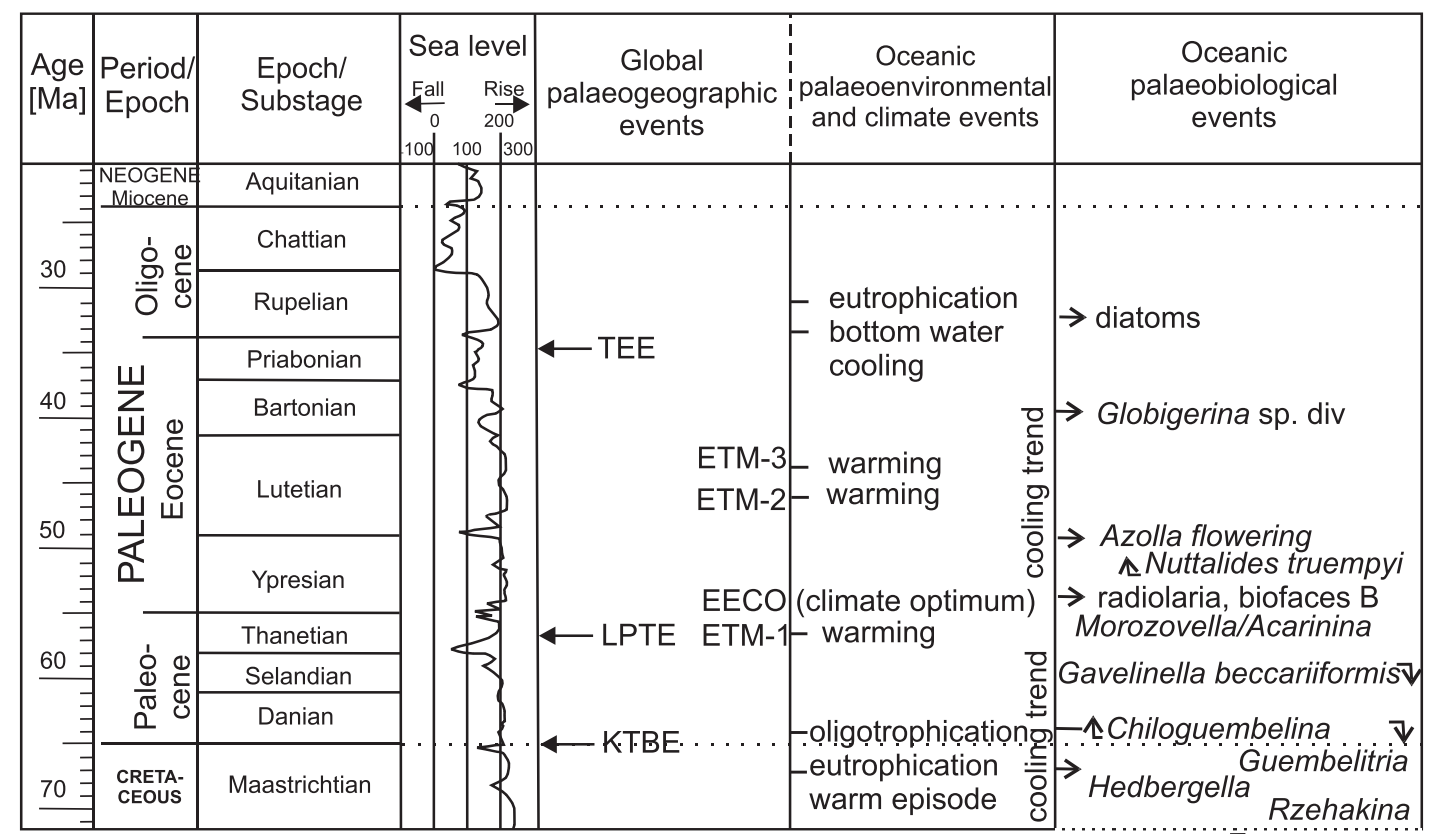

$\checkmark$ C. gigantea

Fig. 1. Global oceanic palaeogeographical, palaeoenvironmental and palaeobiological events in the Latest Mesozoic and Cenozoic with respect to the geochronology and sea level curve, respectively (Berggren et al., 1985; Haq et al., 1987; Aubry et al., 1988; Kuhnt et al., 1992; Erbacher et al., 1999; Kaminski et al., 1999; Keller and Padro, 2004; Kaminski, 2005)

and ornamented tests, which belong to k-strategists, and the appearance of low-oxygen and acidification tolerant dwarf r-strategists can be identified as an example of adaptive radiation associated with drastic ecological changes that took place close to the Maastrichtian-Paleocene, Paleocene-Eocene and EoceneOligocene boundaries (MacLeod, 1993; Luciani et al., 2016). At the end of the Paleocene ( $57 \mathrm{Ma}$ ), changes in hydrothermal activity and circulation in bottom waters and atmosphere, accompanied by global warming (greenhouse effect), led to perturbations in marine environments that resulted in global anoxia (Rea et al., 1990; Kennett and Stott, 1991; Stott, 1992; Speijer et al., 1997; Bains et al., 2000; Fig. 1). The PETM event ( 55.5 Ma) is characterized by globally elevated temperatures and major biotic changes on land and in the oceans, including the extinction of deep-water benthic foraminifera (Galeotti et al., 2004; Arreguín-Rodríguez et al., 2013). At that time, marine plankton and terrestrial organisms were significantly differentiated, while numerous species of flysch-type assemblages became extinct (Kaminski et al., 1995; Kelly et al., 1998; Kelly, 2002). Benthic foraminiferal survived in homogeneous eutrophic assemblages including species of the Glomospira (Biofaces B) biofacies (Kaminski, 2005; Arreguín-Rodríguez et al., 2013; Fig. 1). A decline of acarininids and foraminiferal benthos is paralleled by a marked increase in carbonate content of sediments. It suggests that these intervals of carbonate enrichment, and its specific microfauna, reflects stepwise enhanced carbon participation in marine environments, induced by increasing concentrations of atmospheric carbon dioxide lead to an increase in sea surface temperatures and intense fluvial input of organic-rich terrigenous material from the adjacent land under humid climate conditions at that time (Kelly, 2002; Giusberti et al., 2007; Taucher et al., 2012). Among calcareous foraminifera, aerobic and oligotrophic assemblages were both replaced by species reflecting low oxygenation and enriched with forms occurring in environments that were previously limited to continental shelf (Speijer et al., 1997).
After the thermal optimum, a cooling trend became widespread in the Late Paleogene. Rapid changes were separated by intervals of more stable conditions and occasional warming periods (Berger, 1972; Barron and Baldauf, 1989). The major cooling interval in the Early-Middle Eocene and the earliest Oligocene reflect the reversal of the climate trend seen during the Early Paleogene. It resulted from changes in ocean water circulation and upwelling, which initiated the process of moving masses of cold water to the surface. Under these settings the activity of siliceous plankton abruptly increased (Fig. 1). The dominance of these forms was closely attributed to natural processes (stratification and upwelling) which led to eutrophication. Low-diversity or monospecific assemblages can also be associated with brackish estuarine waters reflecting river influx (diatoms) or mixed waters in the tidal zone (radiolarians) (Boltovskoy et al., 2003; De Wever et al., 2003). Intense decomposition of this biogenic and terrestrial plant material on the sea floor was associated with the consumption of oxygen, which led to anoxic bottom conditions (Vetö, 1987). Poorly diverse epifauna and some shallow- or deep-water infauna prefer this hostile environment including organic-rich sediment and cold stable bottom waters (Sen Gupta et al., 1993; Kaminski et al., 1995; Kaminski et al., 1999; Nagy et al., 2009).

Changes in water geochemistry also reflect a crisis in the marine environment (Zachos et al., 2005). This is manifested by enrichment in trace elements and chemical compounds resulting from the decomposition of organic matter, activity of organisms, and the impact of volcanic and climate factors. Oganic carbon and carbon and hydrocarbon biomarkers usually indicate intense decomposition of land- and marine-derived organic matter owing to microbial processes on the sea floor (Lange et al., 2000). Under these conditions shaped by submarine volcanism, greenhouse gases were released: carbonate dioxide and methane (Vogt, 1989; Jardine, 2011). An increase in the content of these products usually results in both low-oxygen conditions in the basin and a warming effect on the surrounding 
lands. These environmental trends, which led to the elimination of marine benthic fauna and intense vegetation on land, were evidenced by the presence of kaolinite (Thiry, 2000). Other clay minerals (montmorillonite), trace elements ( $\mathrm{Zn}, \mathrm{V})$, and mineral rocks (phosphates) reflect the early diagenesis of sedimentary and volcanic deposits caused by the activity of marine water, chemical compounds and greenhouse gases released during the decomposition of organic debris and hydrothermal activity (Compton et al., 2000; Maslennikov et al., 2012). These processes led to intense oxygen consumption. The extended anoxia in stratified and cold waters favoured the formation of siderite on continental shelves (Berner, 1984; Tucker, 1991; Melinte-Dobrinescu and Roban, 2011).

Fluctuations in the ocean circulation, sea level, the carbon cycle, and climate that contributed to sea surface productivity or bottom conditions during the Paleogene have been identified by the analysis benthic and planktic foraminifers and geochemical indices from the flysch deposits in the Outer Carpathian Basin. In this marginal basin of the northern Tethys, deposition of siliciclastic-carbonate turbidities prevailed. The flysch series dominated by sandstones include shales and local marls that may reflect environmental perturbations associated with changes in water circulation and geochemistry. The widespread occurrence of these conditions was intensified by thermal and salinity changes in the basin studied. The Paleogene flysch series from the Polish Outer Carpathians are examined in order to understand environmental stress and its external settings. This analysis is based on original, archived and published results to determine whether it could occur under the influence of global and regional factors.

\section{GEOLOGICAL AND SEDIMENTOLOGICAL REMARKS}

Environmental changes in the northern Tethyan Sea were analysed based on foraminiferal and geochemical index from the Paleogene flysch series of the Polish Outer Carpathians (Fig. 2). During the Paleogene the study area was a marginal basin very sensitive to relative sea level changes. In this area, presently divided into tectonic zones, the sedimentary system dominated by turbidity currents was strongly controlled by geodynamic processes (Oszczypko, 2004; Jankowski, 2015).

Under these settings, turbiditic siliciclastic-carbonate deposits formed (Koszarski et al., 1974; Ślączka and Kaminski, 1998). Those deposited under low sedimentation rate conditions reflected environmental stress associated with abrupt changes in the water circulation and chemistry. They are represented mainly by shales and occasional marls with siderites, phosphates (Paleocene), tuffites (Paleocene-Eocene) and cherts (Lower Oligocene) and often occur within sandstone se-

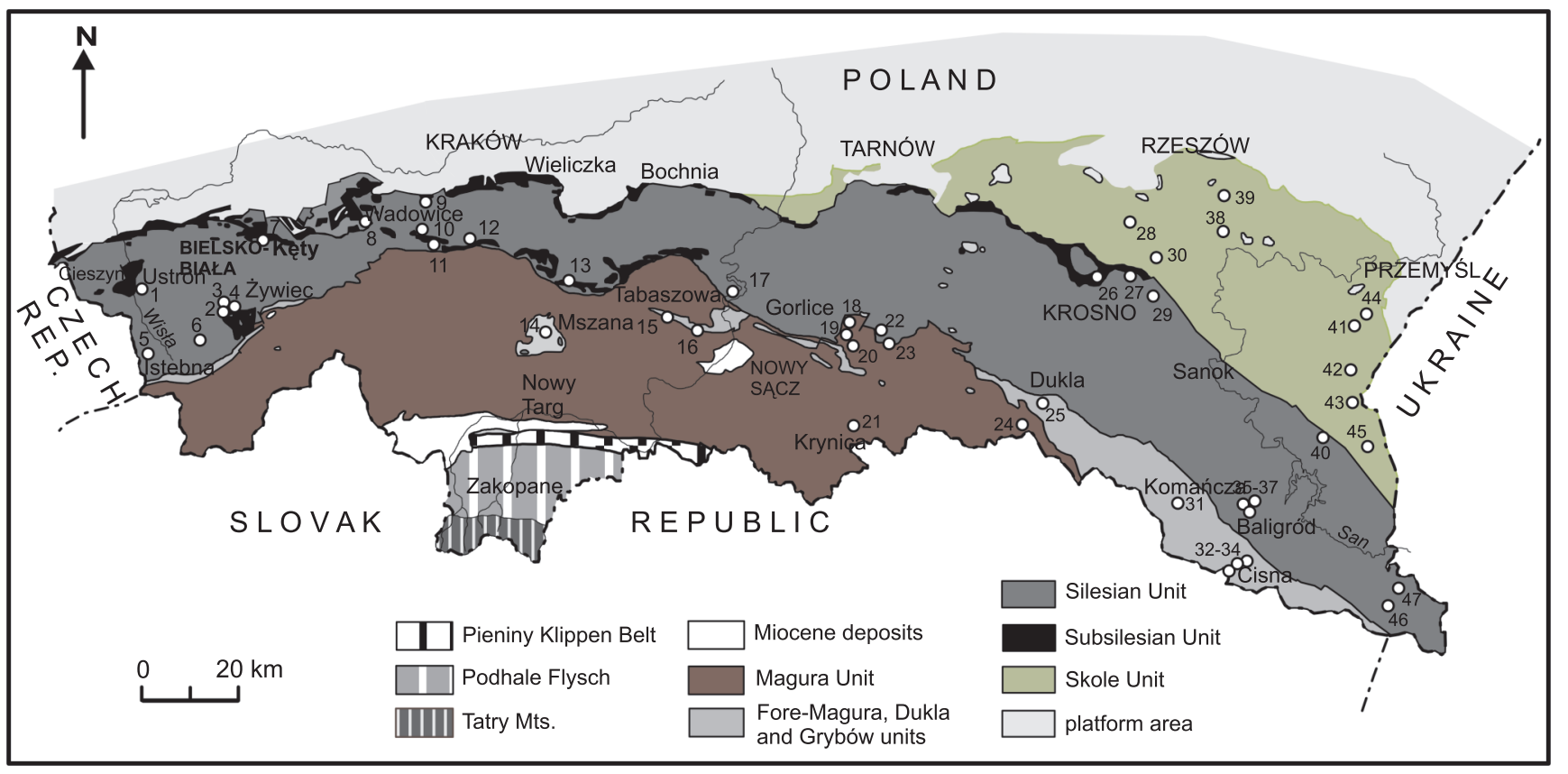

Fig. 2. Location of selected outcrops and boreholes on the background of tectonic units of the Polish Outer Carpathians (modified from Żytko et al., 1989; Oszczypko, 2006)

1 - Ustroń (Istebna Fm.), 2-4 - vicinity of Żywiec Lake (Istebna Fm.; 2 - Mała Tresna, 3 - Oczków, 4 - Wilczy Jar), 5 - Istebna-Olza-Olecka region (Istebna Fm.), 6 - Kamesznica (Istebna Fm.), 7 - Kęty (Variegated Shales), 8 - Wadowice (Menilite Fm.), 9 - Leńcze (Menilite Fm.), 10 - Harbutowice (Menilite Fm.), 11 - Skawinki (Menilite Fm.), 12 - Myślenice (Menilite Fm.), 13 - Stróże (Menilite Fm.), 14 - Mszana Górna (Menilite Fm.), 15 - Cieniawa (Menilie Fm.), 16 - Klęczany (Menilite Fm.), 17 - Tabaszowa (Istebna Fm.), 18 - Bieśnik (Variegated Shales), 19 - Maślana Góra (Variegated Shales), 20 - Ropa, 21 - Magdalena (Menilite Fm.), 22 - Gładyszów (Wątkowa Sandstones, Gładyszów Beds), 23 - Sekówka (Variegated Shales, Magura Beds, Menilite Fm.), 24 - Dukla (Majdan Beds), 25 - Trzciana (variegated shales in Magura Beds), 26 - Węglówka (variegated marly and shaly deposits), 27 - Czarnorzeki (Istebna Fm.), 28 - Godowa (Krosno Fm.), 29 Jasionów (Variegated Shales), 30 - Połomia (Czudec Clays), 31 - Komańcza (Majdan Beds, Variegated Shales, Menilite Fm.), 32-34 Cisna-Majdan-Solinka (Majdan Beds), 35-37 - Baligród-Bystre-Rabe (Menilite Fm., Krosno Fm., Istebna Fm.), 38 - Harta (Krosno Fm.), 39 Hyżne (Variegated Shales, Hieroglyphic Fm.), 40 - Bezmiechowa (Węglówka Marls), 41 - Krępak (Menilite Fm.), 42 - Leszczawa Górna (Menilite Fm.), 43 - Ropienka (Menilite Fm.), 44 - Cisowa (Menilite Fm.), 45 - Brzegi Dolne (Menilite Fm.), 46 - Hulskie (Krosno Fm.), 47 Czarna Góra (Krosno Fm.) 
ries in different proportions and locally form independent lithofacies (e.g., Variegated Shale Fm., Węglówka Marls; Fig. 3). During the Paleocene-Eocene, shales and marls dominated in the external (Skole and Subsilesian units) and, locally, in the inner (northern part of the Magura Unit) zones of the Polish Outer Carpathians. In the Oligocene, shales (Menilite Fm.) became the dominant lithofacies (Koszarski et al., 1974; Malata, 1997; Ślączka and Kaminski, 1998; Fig. 3). Their distribution was strongly controlled by geotectonic and geodynamic processes. Under these conditions, the basin was frequently divided into interconnected sub-basins (Książkiewicz, 1962; Golonka et al., 2000; Jankowski, 2015). As a consequence of this subdivision, deposits that previously accumulated in the same basin currently belong to different tectonic units. Their comparison shows that only the Magura, Silesian and Skole sub-basins could be considered as independent sedimentary areas. While the Subsilesian and Silesian zones were closely related to each other, the Dukla Zone, which was a transitional area between the Silesian and the Magura zones, was individualized and transformed during the Paleogene (Cieszkowski, 2001; Oszczypko, 2004).

Perturbations in marine ecosystems, strongly determined by tectonic history and geological factors, also reflect major palaeogeographic and biotic events. These relations with respect to environmental stress during the Paleogene are discussed in this study.

\section{MATERIAL AND METHODS}

The study is based on samples collected from Paleogene deposits of the Silesian, Subsilesian and Dukla units (Fig. 3). The results include also the data from the Magura and Skole series, which was partly published by the present authors and others. Rock material was collected during geological mapping of the Polish Outer Carpathians on the scale of 1:50,000, and during research conducted by the authors. Most of the samples were taken from outcrops, but some of them come from boreholes. Sampled rocks were disintegrated by boiling and freezing at the laboratory of the PGI-NRI Carpathian Branch in Kraków. The micropalaeontological analysis and photographic documentation of selected material $(63 \mu \mathrm{m})$ was performed using a stereoscopic optical microscope (Zeiss Stereo Discovery.V12). The collected microfossils are described with special focus on the relationship between test morphology and living or feeding strategy, ecological preferences and fossilization potential (Jones and Charnock, 1985; Corliss, 1985, 1991; Bernhard, 1986; Corliss and Chen, 1988; Nagy et al., 1995; Kaminski and Kuhnt, 1995). These results are compared with palaeogeographic events shaped by sea level and oxygenation changes in marine environments. Micropalaeontological data are discussed with respect to water geochemistry and climate fluctuations documented by geochemical indices, including trace elements and minerals and chemical compounds preserved in shales. These data are correlated with sedimentary processes and biotic events reflecting environmental crises during the Paleogene. Changes in the diversity and number of foraminifera observed by the authors are reported with respect to both other microfossils (radiolarians, diatoms, algae) and geochemical data that are part of archived and published studies (Wieser and Gucwa, 1977, 1980; Muszyński et al., 1979; Gucwa and Ślączka, 1980; Olszewska, 1984, 1985; Gucwa, 1990; Gucwa and Poprawa, 1996; Dziubińska and Narębski, 2004; Bieńkowska-Wasiluk, 2010; Zielińska, 2010,
2017; Garecka, 2012; Salata and Uchman, 2012, 2013; Szydło and Olszewska, 2012; Ślączka et al., 2014; Dziadzio et al., 2016). The results compiled by authors are presented against the geochronology and the stratigraphic position of the studied deposits (Fig. 4).

\section{MICROPALAEONTOLOGICAL AND GEOCHEMICAL DATA}

In the Paleogene flysch series, environmental stress and its external settings are mainly evidenced by foraminiferal and geochemical data. The most widespread fossil group is the agglutinated and calcareous benthic foraminifera that are closely related to the sediment and marine waters, and reflect depositional conditions and their duration. Agglutinated foraminifers, as the most numerous group in the study area, include mainly autochthonous forms with tests cemented by silica and sometimes calcium carbonate. Planktic and calcareous benthic forms occur only in parts of the studied deposits that accumulated during some intervals of the Paleogene. These forms are more numerous in the Paleogene Subsilesian series and the Upper Eocene-Oligocene deposits of other tectonic zones (Huss, 1957; Jurkiewicz, 1967; Jednorowska, 1975; Olszewska, 1980; Morgiel and Olszewska, 1978, 1981; Morgiel and Szymakowska, 1978; Olszewska et al., 1996; Olszewska, 1997b). Due to the high fossilization potential, foraminifera are used for palaeoecological and biostratigraphical research in the Polish Outer Carpathians (Geroch et al., 1967; Książkiewicz, 1975; Geroch and Nowak, 1984; Olszewska, 1985, 1997a; Geroch and Koszarski, 1988; Fig. 3). The characteristics of this group with respect to other microfossils (radiolarians, diatoms and algae) and geochemical data are discussed in this chapter.

\section{PALEOCENE}

In the Paleocene dark shales of the Istebna (Silesian Unit) and Majdan Beds (Dukla Unit), siderites and agglutinated foraminifera cemented by silica are found. Species belonging to the genera: Glomospira (G. charoides, G. diffundens, G. gordialis), Glomospirella (Gl. grzybowskii) and Rzehakina (Rz. epigona, $R z$. fissistomata, $R z$. simplex) are recovered from all study areas west of the Soła River and near the Dunajec River and east of it (Fig. 2). Representatives of the genera Haplophragmoides (H. horrides, H. mjatlukae, $H$. stomatus), Recurvoides (R. nucleolus, R. walteri) and Recurvoidella (Re. lamella) are found mainly in localities situated in the eastern part of the Polish Outer Carpathians. They are occasionally accompanied by agglutinated foraminifera of the genera Kalamopsis, Ammodiscus, Caudammina, Trochamminoides, Saccammina, Reophax and Bolivinopsis (Fig. 4). Some of these genera are also reported from variegated shales of the Istebna Formation. Other siliceous and calcareous microfossils also sporadically occur in these series. The former are represented by radiolarians and diatoms dispersed in the studied deposits or are present at the top of them, while calcareous foraminifera occasionally occur in muddy flows and shales. The appearance of calcareous forms, which was reported from the vicinity of Żywiec Lake (Nescieruk and Szydło, 2003), was also confirmed in the Krosno region (Figs. 2 and 4). Single specimens of calcareous benthic (Nuttalides trumpyi, Gyroidinoides nitidus) and planktic species (Eoglobigerina trivialis, Subbotina triloculinoides, Chiloguem- 


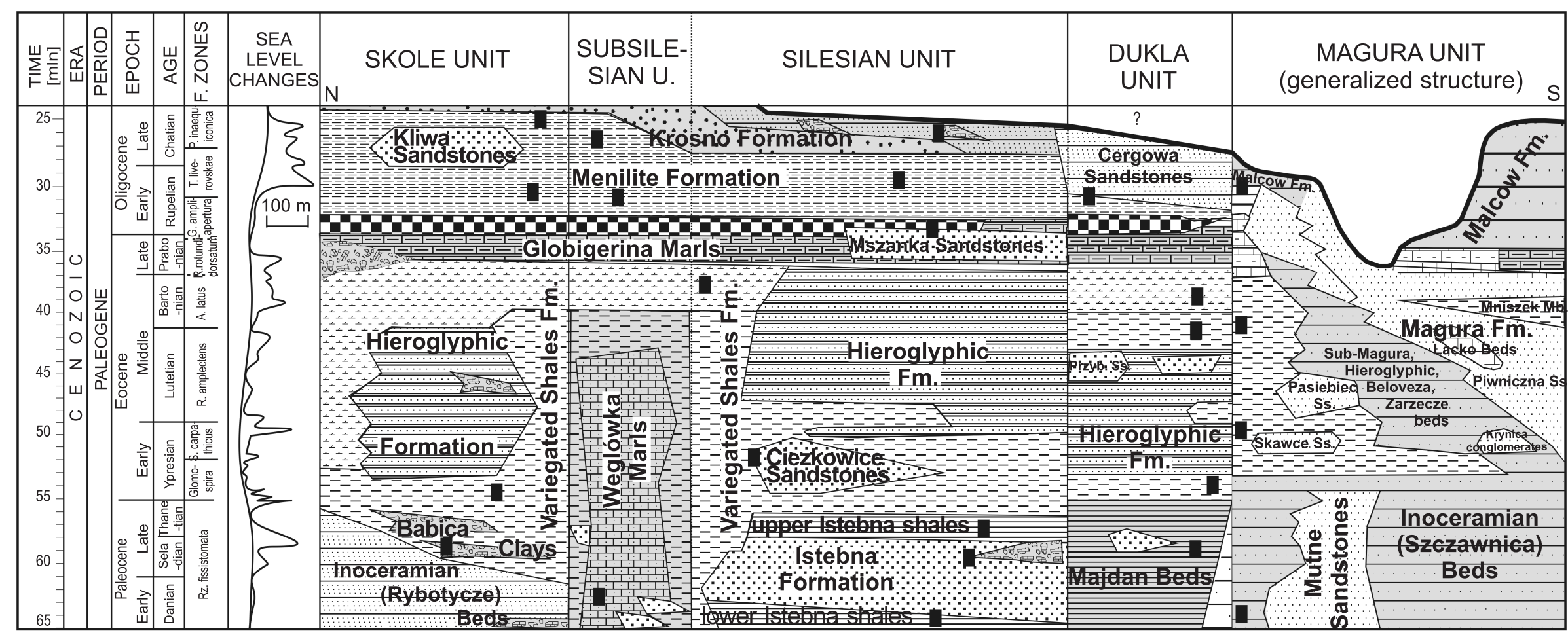

black shales

spotty marls

i. nodular limestones

cherty limestones

EII hornstones

$\therefore$ siliceous spicule rich deposits

calcareous turbidities massive turbidite marls

thin- to thick-bedded calcareous sandstones, shales

$\ldots \ldots$ medium to thin bedded sandstones, shales

$\ldots$ thin to medium bedded sandstones, black shales

$\because \because \because$ thick-bedded sandstones $\because \because$ thick-bedded sandstones, conglomerates

\section{calcareous deposits}

non-calcareous deposits

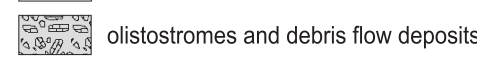

- studied deposits

Fig. 3. Generalized lithology and stratigraphy of the studied deposits (Geroch and Nowak, 1984; Olszewska, 1997a; Ślączka and Kaminski, 1998; Leśniak et al., 2001; Oszczypko, 2004; compiled and modified) 


\begin{tabular}{|c|c|c|c|c|c|c|c|c|c|c|c|c|c|}
\hline \multirow[b]{2}{*}{ PLANKTON } & \multicolumn{4}{|c|}{ PALEOCENE } & \multicolumn{3}{|c|}{ EARLY EOCENE } & \multicolumn{2}{|c|}{$\begin{array}{l}\text { EARLY/MIDDL } \\
\text { E-LATE EOCENE }\end{array}$} & \multicolumn{2}{|c|}{$\begin{array}{l}\text { EARLY - LATE } \\
\text { OLIGOCENE }\end{array}$} & AGE & 号 \\
\hline & $\begin{array}{c}\text { DARK AND } \\
\text { VARIEGATED } \\
\text { SHALES } \\
\text { (Istebna } \mathrm{Fm} \text {.) }\end{array}$ & $\begin{array}{c}\text { VARIEGATED } \\
\text { MARLS AND } \\
\text { SHALES } \\
\text { (Węglówka } \\
\text { beds) }\end{array}$ & $\begin{array}{c}\text { BLACK } \\
\text { SHALES } \\
\text { (Majdan } \\
\text { beds) }\end{array}$ & $\begin{array}{c}\text { VARIEGATED } \\
\text { SHALES } \\
\text { (Inoceramian } \\
\text { beds) }\end{array}$ & $\begin{array}{c}\text { VARIEGATED } \\
\text { SHALES (with } \\
\text { Ciężkowice } \\
\text { Ss.) }\end{array}$ & $\begin{array}{c}\text { VARIEGATED } \\
\text { SHALES }\end{array}$ & \begin{tabular}{|c|} 
VARIEGATED \\
SHALES (with \\
Hieroglyphic \\
Ss.)
\end{tabular} & \multicolumn{2}{|c|}{$\begin{array}{l}\text { VARIEGATED } \\
\text { SHALES AND } \\
\text { BLACK CLAYS }\end{array}$} & \multicolumn{2}{|c|}{$\begin{array}{c}\text { DARK SHALES } \\
\text { (MENILLTE FM, } \\
\text { KROSNO FM.) }\end{array}$} & LITHOLOGY & 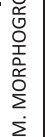 \\
\hline Foraminifera (o) & $\begin{array}{l}\text { SILESIAN } \\
\text { ZONE }\end{array}$ & $\begin{array}{c}\text { SUBSILESIAN } \\
\text { ZONE }\end{array}$ & DUKLA ZONE & $\begin{array}{l}\text { MAGURA } \\
\text { ZONE } \\
\text { (northern }\end{array}$ & $\begin{array}{l}\text { SILESIAN } \\
\text { ZONE }\end{array}$ & $\begin{array}{l}\text { SUBSILESIAN, } \\
\text { MAGURA } \\
\text { (northern }\end{array}$ & $\begin{array}{l}\text { SKOLE ZONE } \\
\text { DUKLA ZONE }\end{array}$ & \multicolumn{2}{|c|}{$\begin{array}{l}\text { ALL TECTONIC } \\
\text { ZONES }\end{array}$} & \multicolumn{2}{|c|}{$\begin{array}{l}\text { ALL TECTONIC } \\
\text { ZONES }\end{array}$} & TECTONIC ZONES & 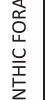 \\
\hline Laterostomella cubensis & & & & & & & & & o & & & Psammosiphonella cylindrica & $\leq$ \\
\hline Chiloguembelina crinita & o & o & & & & & & & & & & Nothia robusta & \\
\hline Ch. morsei & $\circ$ & $\circ$ & & & & & & & & & $\circ$ & N. excelsa & 岁猋 \\
\hline Ch. gracillima & & & & & & & & & o & o & o & N. latissima & \\
\hline Globoconusa daubjergensis & & 0 & & & & & & & & & & Saccammina placenta & \\
\hline Eoglobigerina fringa & & & & 0 & & & & & & & & Ammodiscus bornemanni & \\
\hline E. trivialis & & 0 & & & & & & & & & & A. latus & \\
\hline Globigerina ampliapertura & & & & & & & & & o & $\circ$ & & Glomospira charoides & \\
\hline Glb. crymptomphala & & & & & & & & o & $\circ$ & & & G. gordialis & \\
\hline Glb. (Subbotina) eoceana & & & & & & & & o & o & & & G. glomerata & \\
\hline Glb. euraperta & & & & & & & & $\circ$ & 0 & & & G. irregularis & \\
\hline Glb. juvenilis & & & & & & & & $\circ$ & o & & & G. serpens & \\
\hline Glb. karpatica & & & & & & & & & $\mathrm{o}$ & $\circ$ & o & Glomospirella diffundens & $\sum$ \\
\hline Glb. leroyi & & & & & & & & & o & $\circ$ & o & Gl. grzybowskii & \\
\hline Glb. officinialis & & & & & & & & & o & $\circ$ & & Hormosina velascoensis & \\
\hline Glb. ouachitaensis & & & & & & & & & o & $\circ$ & o & Caudammina excelsa & \\
\hline Glb. praebulloides & & & & & & & & & o & $\circ$ & o & Ca. ovulum & $\leq$ \\
\hline Murciglobigerina senni & & & & & & & & & 0 & & & Trochamminoides coronatus & 5 \\
\hline Globanomalina micra & & & & & & & & o & 0 & o & & Trochammina globigeriniformis & ㄲㅗㅡ \\
\hline Ga. naguewichensis & & & & & & & & & & $\circ$ & & Lituotoba lituiformis & \\
\hline Subbotina triloculinoides & o & & 0 & & & & & & & $\circ$ & & Ammolagena clavata & \\
\hline S. hagni & & & & & & & & & $\circ$ & & & C-lla pseudopauciloculata & \\
\hline S. linaperta & $\circ$ & $\circ$ & & $\circ$ & & & & o & $\circ$ & & & Rzehakina epigona & \\
\hline S. angiporoides & & & & & & & & & $\mathrm{o}$ & $\circ$ & & Rz. fissistomata & \\
\hline S. krosnensis & & & & & & & & & o & $\circ$ & & Rz. simplex & \\
\hline S. droogeri & & & & & & & & & & o & & Reticulophragmium amplectens & \\
\hline Globoquadrina selli & & & & & & & & & & $\circ$ & & Ret. rotundidorsatum & \\
\hline Parasubbotina inaequispira & & & & & & & & o & & & & Nuttalides truempyi & \\
\hline P. pseudobulloides & o & & & & & & & & & & & Cibicides amphisylensis & \\
\hline P. varianta & o & & & & & & & & & & & Ci. lopjanicus & \\
\hline Planorotalites pseudomenardii & o & & & & & & & & & & & Melonis affinae & \\
\hline Acarinina graveli & & & & & & 0 & & & & & & Haplophragmoides horridus & \\
\hline A. brodermanii & & & & & & & & & 0 & & & H. mjatlukae & \\
\hline A. bulbrooki & & & & & & & & & 0 & & & H. stomatus & z \\
\hline A. mcanai & & & & o & & & & & & & & H. walteri & 岳 \\
\hline A. primitiva & $\circ$ & & & & 0 & 0 & & & & & & Recurvoides nucleolus & $\overline{3}$ \\
\hline A. spinoinflata & & & & & & & & & 0 & & & Reo. walteri & Z \\
\hline Testacarinata rugosoaculeata & & & & & & & & & o & o & & Recurvoidella lamella & 吾 \\
\hline Morozovella aequa & $\circ$ & & & & & 0 & & & & & & Cribrostomoides suborbicularis & \\
\hline M. marginodentata & o & & & & & & & & & & & Chilostomella tenuis & \\
\hline M. velascoensis & o & & & & & & & & 0 & & & Nonionella liebusi & \\
\hline Catapsydrax dissimilis & & & & & & & & & o & & & Allomorphina trigona & \\
\hline C. primitivus & & & & & & & & & o & $\circ$ & & Kalamopsis grzybowskii & \\
\hline Globorotaloides suteri & & & & & & & & & o & $\circ$ & o & Saccamminoides carpathicus & \\
\hline Cassigerinella chipolensis & & & & & & & & & & & $\circ$ & Reophax duplex & \\
\hline Tenuitellinata angustiumbilicata & & & & & & & & & o & o & & R. pilulifer & \\
\hline Te. ciperoensis & & & & & & & & & & $\circ$ & $\circ$ & Karrerulina coniformis & \\
\hline Te. postcretacea & & & & & & & & & & o & $\circ$ & Gerochammina conversa & \\
\hline Tenuitella denseconnexa & & & & & & & & & & & o & Bolivinopsis spectabilis & 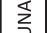 \\
\hline T. brevispira & & & & & & & & & & o & o & Remesella varians & 崖 \\
\hline T. munda & & & & & & & & & & & o & Bulimina polymorphinoides & $\frac{m}{a}$ \\
\hline T. liverovskae & & & & & & & & & 0 & $\circ$ & & Globobulimina pyrula & 㟔 \\
\hline T. inaequiconica & & & & & & & & & & & o & Bolivina crenulata & \\
\hline T. wilsoni & & & & & & & & o & & & & Virgulina dibolensis & \\
\hline Paragloborotalia nana & & & & & & & & & & & o & Virgulinella karagiensis & \\
\hline Globigerinella obesa & & & & & & & & & & & o & Caucasina coprolithoides & \\
\hline Radiolarians (x) & $\mathbf{x}$ & & $\mathrm{x}$ & & $\mathrm{x}$ & $\mathrm{x}$ & $x$ & & $x$ & & & Uvigerina multistriata & \\
\hline Diatoms $\left({ }^{*}\right)$ & $*$ & & $*$ & & & & & & & * & $*$ & Fursenkoina schreibersiana & \\
\hline
\end{tabular}

Fig. 4. The variability of foraminifera in studied deposits with special focus on benthic morphogroups and distribution of planktic foraminifera and phytoplankton 
belina crinita, Ch. morsei, Morozovella velascoensis and $P$. pseudobulloides) are characteristic for these assemblages. Rarely, they contain Planorotalites pseudomenardii and Acarinina mcanai that indicate the upper part of the Paleocene (Fig. 4). Organic debris also accumulated in mudstones and mudstone-sandy series of the Istebna Formation (Zielińska, $2010,2017)$. This abundant and usually dispersed material of terrestrial origin co-exists with very rare dinocysts in samples from the vicinity of Kamesznica (Szydło et al., 2015a, b).

Similar agglutinated assemblages with Rzehakina were also documented in other tectonic units of the Polish Outer Carpathians (Jurkiewicz, 1967; Jednorowska, 1975; Olszewska et al., 1996). It was confirmed by the authors in the Subsilesian (Węglówka Marls), Dukla (Majdan Beds) and Magura series (Variegated Shales) (Fig. 4). Moreover, foraminiferal and radiolarian plankton found in the Istebna Formation was also described in variegated deposits of the Subsilesian (Huss, 1957; Jednorowska, 1975; Olszewska, 1980; Waśkowska-Oliwa, 2005, 2008) and Dukla units (Olszewska, 1980). However, they usually contain numerous planktic foraminifera. These forms, belonging mainly to the genera Globoconusa (G/c. daubjergensis), Preamurica (Pr. ucinata), Morozovella (M. angulata), Eoglobigerina (E. fringa), Subbotina (S. triloculinoides), Parasubbotina ( $P$. pseudobulloides) and Chiloguembelina (Ch. morsei, Ch. crinita), sometimes co-exist with calcareous benthic taxa (Nuttalides, Anomalina) (Fig. 4). In addition, specimens of Guembelitria are occasionally found in shales accompanied with the Inoceramian sandstones of the Skole Unit at the Cretaceous/Paleogene boundary (Gasiński and Uchman, 2011).

Organic matter is usually oxidized in variegated deposits. However, shaly marls of the Subsilesian Unit (Bezmiechowa) locally contain organic matter of marine origin (Szydło et al., 2015b), while the variegated shales of the Skole Unit contain phosphates and lenses of black clayey and muddy flows which also occur in the Babica Clays (Franus and Rajchel, 2002; Szydło et al., 2014; Fig. 4). Pyritization process was observed in these series (Szydło et al., 2014).

\section{EOCENE}

Homogeneous agglutinated foraminiferal assemblages containing Glomospira species ( $G$. charoides, G. gordialis), and associations with Saccamminoides (Sa. carpathicus) are characteristic for the Early Eocene (Jurkiewicz, 1967). This microfauna is known from shales of variegated colours (variegated shales) which are accompanied by the Ciężkowice (Silesian Unit), the Magura (Magura Unit) and the Hieroglyphic sandstones (Dukla and Skole units) or form separate lithostratigraphic units (Variegated Shales) in the Subsilesian zone (Olszewska, 1973, 1980; Waśkowska, 2008, 2015; Fig. 2). Over most of the study area the Eocene shales contain Bolivinopsis spectabilis and, locally, Ammodiscus latus, which periodically occur in high number (Fig. 4). Variegated shales of the Skole Unit were deposited in the Paleocene-Eocene. They contain radiolarians, tuffites, specific minerals: montmorillonite and kaolinite (Fig. 4), $\mathrm{Mn}$ and Fe oxide micro-concretions, and $\mathrm{Mn}, \mathrm{Fe}, \mathrm{Mg}$ and $\mathrm{Ca}$ oxides and carbonate concretions (Muszyński et al., 1979; Bak et al., 1997; Franus and Rajchel, 2002). Changes in plankton were also initiated at that time. This biotic process continued to the Middle Eocene and was associated with the occurrence of Morozovella (M. marginodentata), Acarinina ( $A$. spinoinflata, $A$. bulbrooki), Turborotalia ( $T$. frontosa) and Hantenkina species, which were described from samples collected by the present authors (Fig. 4) and others
(Nowak, 1954; Gasiński, 1978). Some of them were found in black clays that occasionally occur in the Skole series (Hieroglyphic Formation). Benthic taxa of the genus Reticulophragmium (Ret. amplectens, Ret. rotundidorsatum), sometimes occurring in low-diversity assemblages (Jurkiewicz, 1967), were encountered in the Middle and Upper Eocene variegated shales of the Subsilesian (Kęty borehole) and Dukla units (Komańcza; Olszewska, 1973; Fig. 4). Radiolarian horizons in the Eocene variegated shales are usually associated with pyritization (Bakk and Barwicz-Piskorz, 2006).

\section{OLIGOCENE}

The next change among planktic foraminifera is observed at the Eocene/Oligocene boundary in most areas of the Polish Outer Carpathians (Olszewska, 1985). Massive and ornamented forms disappeared at that time. Thick-walled taxa of Globigerapsis index, Gs. coccoensis, Turbolotaria cerroazulensis and Glb. amplipertura were replaced by small-sized specimens with spinose and thin-walled tests and globular chambers (Globigerina praebulloides, Glb. occlusa, Glb. ouachitaensis, Cassigerinella chipolensis, Glb. officinalis and Tenuitellinata liverovskae), and others having partly covered aperture and an additional chamber or apertures. Forms belonging to Catapsydrax (C. dissimilis, C. unicavus), Globorotaloides (Glo. suteri), Subbotina (S. droogeri), Globoquadrina (Gq. selli) occur both in the external (Skole) and internal (Magura) units (Fig. 4). They are accompanied in the Menilite Beds by other forms belonging to Globanomalina and Chiloguembelina, which are known from the Late Eocene variegated shales (Olszewska, 1973, 1985; Fig. 4). The Eocene-Oligocene boundary coincides with almost total disappearance of agglutinated taxa that were replaced by calcareous benthic forms of the genera Bolivina, Chilostomella, Allomorphina, Nonionella, Globobulimina, Fursenkoina, Caucasina, Virgulina and Virgulinella (Olszewska, 1985) found in the Dukla, Silesian and Magura units (Fig. 4). Benthos with pyritized tests is represented by the genus Cibicides. These forms occur in organic-rich Menilite Shales that were widespread in the Outer Carpathians during the Oligocene (Olszewska, 1985). Remains of diatoms and fish are also found in these shales. After the Early Oligocene dominance of calcareous benthos occurring in homogeneous assemblages, planktic foraminifera became more numerous in the Late Oligocene. In shales of the Krosno sandstones, assemblages with benthic and planktic opportunistic forms (Globigerina officinalis, Glb. ouachitensis, Glb. praebulloides) were replaced by an association composed of Tenuitellinata angustiumbilicata, Te. ciperoensis and Te. postcretacea. This type of microfauna was found in mud flows (Fig. 4).

The Menilite Shales also include many trace and mineral elements: $\mathrm{Ni}, \mathrm{Cr}, \mathrm{Mn}, \mathrm{Mo}, \mathrm{Zn}, \mathrm{V}, \mathrm{Cu}$ and $\mathrm{SiO}_{2}$. Among clay minerals, montmorillonite prevails (Wieser and Gucwa, 1977; Gucwa and Wieser, 1980; ten Haven et al., 1993; Gucwa and Poprawa, 1996). Some poarts of the Menilite Shales are predominantly of biotic origin. More external zones (Skole, Subsilesian, and Silesian units) abound in $\mathrm{V}$ and Mo, while the enrichment in $\mathrm{Cu}$ is characteristic of the internal part of the Polish Outer Carpathians (Gucwa and Ślączka, 1980; Gucwa, 1990; Fig. 4). Moreover, hydrocarbon biomarkers, including norhopanes/hopanes, isoprenoids, diasteranes and oleananes, have been documented in the Meniliite shales of the Silesian and Magura units. Hopane and sterane biomarkers have also been documented in the Upper Eocene green shales of the Silesian Unit (Sękówka), which underlie the Menilite Shales Formation including siliceous marls (Dziadzio et al., 2016). 


\section{CHANGES IN DEPOSITIONAL ENVIRONMENTS}

The siliceous-carbonate flysch deposition heavily influenced the marine biota and preservation of organic debris. Hemipelagic deposition which prevailed in the Subsilesian Zone and in part of the Magura and Skole zones was frequently interrupted by the abrupt supply of coarse-grained terrigenous material in the Silesian and Dukla zones (Leśniak et al., 2001; Strzeboński, 2015; Fig. 3). This process, controlled by turbidity currents, usually led to mechanical destruction of biogenic material that was strongly reworked and rapidly oxidized on the seafloor. Its de- composition during long periods of low tectonic activity and limited water circulation contributed to oxygen consumption and the release of greenhouse gases $\left(\mathrm{CO}_{2}, \mathrm{CH}_{4}\right)$ (Fig. 5). This process, associated with the activity of anaerobic bacteria and shaped by submarine volcanism (tuffites), led to anoxia under humid warm conditions (kaolinite). This phenomenon spread at different range and time in the Outer Carpathian Basin. During progressive anoxia, foraminifera migrate to the sediment and water surface. Their distribution on the sea floor related to life position, their feeding strategy and test structure, and oxygen availability (Jones and Charnock, 1985; Bernhard, 1986; Nagy et al., 1995; Kaminski and Kuhnt, 1995; Kaminski, 2012). In stratified and turbid waters, agglutinated and calcareous benthics occurred as
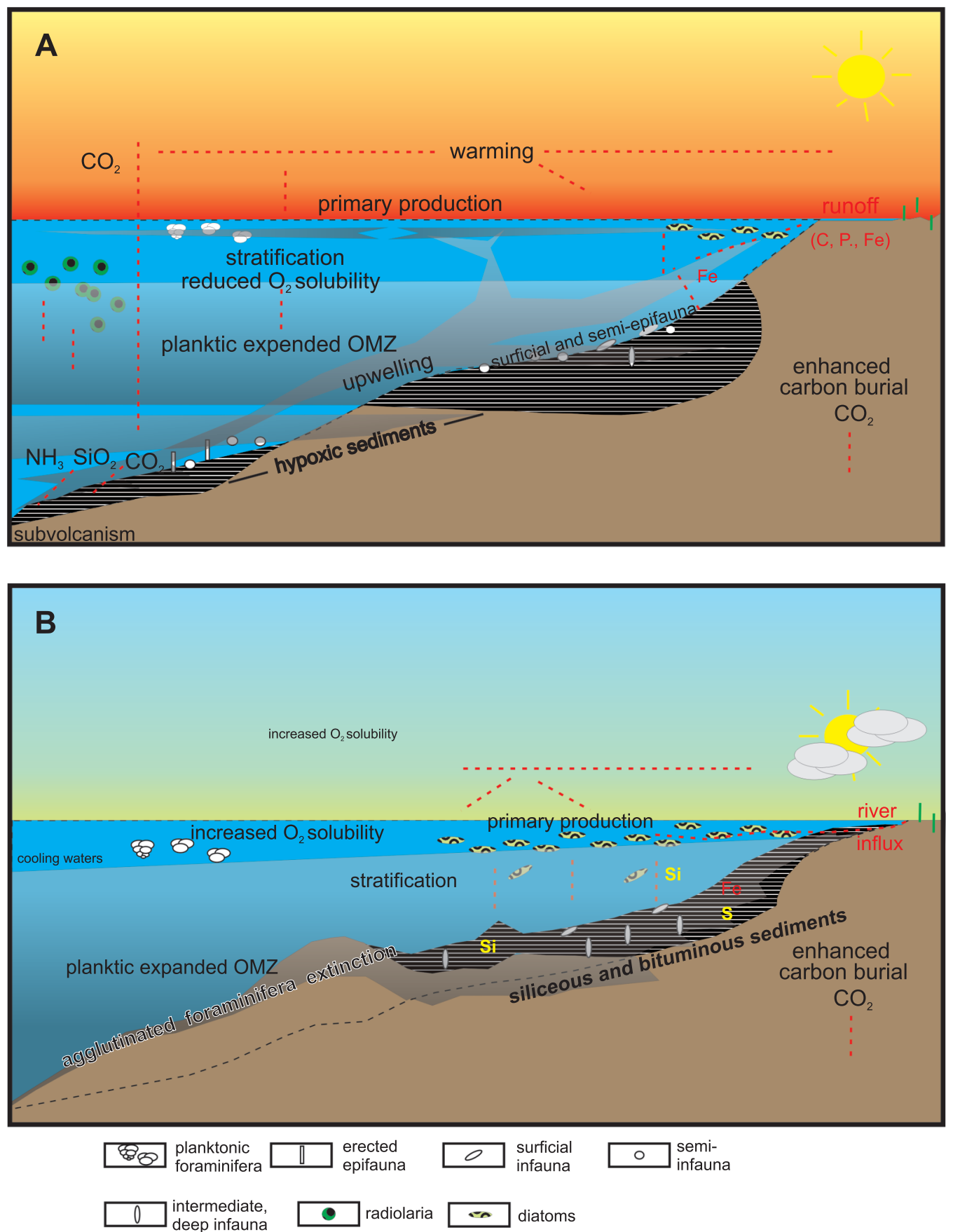

Fig. 5. Hypothetical diagram illustrating the activity of marine microorganisms and a change in water chemistry under environmental and climatic conditions: A - Paleocene-Eocene warming, B - Oligocene cooling (Praetorius et al., 2015, modified) 
epi- and infauna representing detritus, deposit and bacteria feeders. During periods of total anoxia in the bottom waters the foraminiferal benthos was eliminated, while shallow-dwelling siliceous (radiolarians, diatoms) and calcareous plankton (foraminifera) dominated in the surface waters (Fig. 5).

In the Paleocene and Eocene, active epifauna (Rzehakina, Ammodiscus) colonized most sediments from coarse- to very fine-grained facies, attaching to the substrate. It seems that because of living strategy and environmental preferences this small involute epifauna and shallow-water ovate infauna (Glomospira and Caudammina) were better adapted to the frequently and rapidly changing environments shaped by turbiditic deposition. Moreover, assemblages dominated by species of the genus Glomospira (G. charoides, G. gordialis, G. diffundens) occurring under lower oxygenation also existed in dysoxic waters during the formation of variegated shales especially in the Early Paleocene and Early Eocene (Fig. 5A). This biotic episode occurs across most of the Polish Outer Carpathians. The last period was also documented in the surface waters by the radiolarian bloom in the Skole Zone (Bak et al., 1997). The infauna with coarse-grained tests cemented by siliceous (Karrerulina, Gerochammina) and calcareous material (Remesella) also existed in more detrital sediment close to the CCD under progressive oxygenation, which was induced by an increased activity of bottom currents. In addition, deep infaunal forms of the genus Bolivinopsis, reflecting cool, turbid and poorly oxygenated bottom waters including pelagic substrates with high organic matter content (Kaminski, 1984), also occur in variegated shales. The Paleocene-Eocene shales also contain specimens of shallow (Recurvoides) and mobile infauna (Haplophragmoides) which, along with species of Bolivinopsis and Ammodiscus, often occur in eutrophic assemblages sensu Haig (1979). This trend is especially characteristic for the lower/middle part of the Eocene (Kaminski, 2005). Usually opportunistic benthic taxa (Glomospira, Caudammina, Recurvoides, Haplophragmoides) which were regarded as forms of the flysch-type by Gradstein and Berggren (1981) highly contribute to the foraminiferal assemblages from habitats that experience periodic anoxia (Kaminski et al., 1995; Figs. 1 and 4). This phenomenon was also observed in the surface waters, as documented by dwarfed forms of the Globigerina group and Chiloguembelina and Guembelitria taxa (Figs. 1, 4 and 5). This plankton tolerates nutrient-rich and anoxic waters that were partly infiltrated by greenhouse gases and toxic compounds transported from the bottom water during intense upwelling in the Paleocene. Especially most of benthic and planktic forms were eliminated just after the KTBE event in the earliest Paleocene (Keller and Benjamini, 1991; Keller and Pardo, 2004). At that time, perturbation in sea level and water circulation led to the extension of anoxia and acidification in parts of the basin. The formation of iron compounds (siderites) and phosphates intensified the process associated with intense consumption of oxygen, which led to the mass extinctions and may confirm the influence of submarine volcanism (Berner, 1984; Keller, 1989; Tucker, 1991). The conditions shaped by diastrophic and hydrothermal processes were also observed during the Paleocene-Eocene (Oszczypko, 2004; Waśkowska et al., 2014; Jankowski, 2015). Replaced calcareous planktic and benthic foraminifera and phytoplankton (red algae) described by the authors and Leszczyński et al. (2012) in the Silesian series (Istebna shales) reflect major relative sea level changes in the Late Paleocene. This process influenced the water circulation and oxygen availability. Planktic massive and ornamented species of Morozovella and Acarinina were eliminated, while mono-species assemblages with semi-infaunal forms of Glomospira charoides and G. gordialis dominated under eutrophic conditions (Figs. 1 and 4). During extending the periods of oxygen deficiency (hypoxia), planktic communities were dominated by radiolarians in the Early and Middle Eocene (Bak et al., 1997). These biotic events may correlate with upwelling and periodic cooling. Under these conditions, early diagenesis (phosphates) took place in stratified waters under the influence of volcanic fluids and gases. It was associated with oxygen and calcium consumption. After this thermal minimum, epifaunal forms of the genus Rethiculophragmium became numerous and occurred in homogeneous eutrophic assemblages in the Middle and Late Eocene (Fig. 4). The periods of anoxia associated with a decrease in sedimentation rate and cooling effect at the beginning of the Paleocene and the Eocene (PETM, EEOC) were interrupted by intense supplies of coarse-grained material. Initially, this process led to short-term oxygenation during the formation of sandstone bodies in the Subsilesian, Silesian, and Dukla zones (Fig. 3). Dysoxic conditions spread gradually into the internal and external zones of the Outer Carpathian Basin (Hieroglyphic and Magura sandstones) during the Eocene (Fig. 3). It seems that deep and shallow infauna (Bolivinopsis, Recurvoides, Haplophragmoides, Glomospira), usually existing in dark shales under low oxygenation conditions, survived periods of deoxygenation during the formation of variegated shales in the early part of the Paleogene. The intensity of this trend is also evidenced by oligotrophic associations with Nuttalides truempyi in the Late Paleocene (Figs. 1 and 4). Moreover, assemblages with thick, coarsely agglutinated species of Saccamminoides reflect periods of supply of coarse grained material in the Early Eocene. It has been found in pelagic and hemipelagic sediments of nutrient-rich environments close to or below the CCD (Waśkowska, 2008, 2014a). In the Early/Middle and Late Eocene, benthic environments were inhabited by assemblages dominated by shallow infaunal species of Reticulophragmium, which became more diverse at the end of these periods. This microfauna, accompanied by Nothia excelsa and Ammolagena clavata, is found in variegated and green shales which formed intercalations within the Hieroglyphic sandstones, and in thick complexes in most parts of the Polish Outer Carpathians (Jurkiewicz, 1967; Waśkowska, 2014a, b, 2015). In the Late Eocene, radiolarians of variegated shales decrease in number (Barwicz-Piskorz and Rajchel, 2012).

Climate changes were initiated during the formation of the Globigerina Marls at the Eocene/Oligocene boundary. It was associated with a palaeogeographic reorganization and changes in ocean circulation (TTE), which resulted in the reactivation of volcanism, sea level fluctuations and a limited deep-water circulation. Under these conditions, forms characteristic for eutrophic conditions (Globanomalina and Chiloguembelina) occurred at this boundary. After this episode, a cooling trend intensified in the Early Oligocene. The Menilite Shales include siliceous nodules (cherts) containing poorly diversified assemblages with calcareous benthic forms that reflect shelf environments (Olszewska, 1984). The replacement of the original fossil material by pyrite is characteristic for this assemblage. Species belonging to the genus Bolivina prefer a shallow, infaunal microhabitat, and dominate in unstable sedimentary environments rich in organic matter. The other deep and intermediate infauna of the genera Chilostomella, Nonionella, Globobulimina and Uvigerina indicate oxygen deficiency in the bottom water (Boersma, 1986; Corliss and Chen, 1988; Kaiho, 1994; Jorissen et al., 1995; Pérez et al., 2001; Hess and Jorissen, 2009). These infaunal and epifaunal forms (Cibicides) with unornamented and smooth tests often occurred in homogeneous eutrophic assemblages (Jorissen et al., 1995; Van der Zwaan et al., 1999; Fontanier et al., 2007). The scarcity or lack of benthos and the dominance of siliceous and organic phytoplankton may reflect periodic decreases in salinity. In limited parts of the basin the influx of land-derived organic matter and 
river waters created low-salinity surface zones colonized by brown algae, cyanobacteria ( $\mathrm{Zn}, \mathrm{Cu}$, dinor-hopanes) and diatoms ( $\mathrm{V}$, isoprenoids) during the Oligocene cooling (ten Haven et al., 1993; Köster et al., 1998; Fig. 5B). Similarly to the previous episodes, periods of anoxia and acidification were interrupted by diastrophic processes that led to the reactivation of water circulation and deoxygenation by an intense supply of terrigenous material (Krosno sandstones). Initially, this process affected surface water while the sea-floor conditions were still restrictive. The Krosno Beds contain pyritized tests of opportunistic plankton and epifaunal benthos that occur in the shaly intercalations of the Krosno sandstones. Moreover, representatives of stressed environments (Globigerina, Cassigerinella, Chiloguembelina and Globanomalina), belonging to the surface-dwelling group and typical of cooler water conditions during the Early Oligocene, were replaced by thermophile foraminiferal plankton that reflect the short-term warming at the end of the Paleogene (Olszewska, 1984; Spezzaferri and Premoli Silva, 1991; Spezzaferri and Spiegler, 2005; Olszewska and Malata, 2006).

\section{DISCUSSION}

Oxygen deficiency and acidification, controlled by diastrophic and hydrothermal processes, affected the benthic and planktic biota during the Paleogene. The studied microfauna tolerates siliciclastic influx caused by drastic sea level changes during periodic marine floodings. Under conditions of humid warm (Paleocene-Eocene) or cold (Oligocene) climate, intense continental runoff led to progressive acidification and hypoxia of stratified waters in which sparse, poorly diversified foraminiferal assemblages were dominated by epifauna (Nagy et al., 2009) and some infauna. These detritus and active deposit feeders relate to the flysch assemblages with Rzehakina and Glomospira-Ammodiscus (Biofacies B) and Recurvoides assemblages occurring under eutrophic conditions (Haig, 1979; Kaminski et al., 1999) (Figs. 1, 4 and 5). The species that tolerate changing oxygen conditions also occur in variegated shales. Under conditions of reduced clastic supply, the genera Nothia and Ammolagena proliferated. They are characteristic for more oxygenated bottom environments close to the CCD (Kaminski and Geroch, 1992; Alve et al., 2011; Waśkowska, 2014b). Frequent supplies of coarse-grained terrigenous material controlled by turbidity currents contributed to the renewal of bottom waters in which opportunistic forms were replaced by oligotrophic taxa. These conditions drastically changed in the Late Paleocene and Early Oligocene. It was associated with the reorganization of the basin and relative sea level fluctuations induced by diastrophic and geodynamic processes. These processes are documented by calcareous planktic and benthic forms, some with pyritized tests. Changes in the plankton populations were closely associated with intense upwelling and acidification. This process was closely associated with hydrothermal and diagenetic processes and biotic decomposition of marine and land-driven plant organic matter, as evidenced by hydrocarbon biomarkers (Lange et al., 2000). In stratified nutrient-rich waters infiltrated by products of hydrothermal and diagenetic processes (gases and liquids), extended anoxia led to the gradual elimination of the biota including benthos (foraminifera, bivalves), nekton (fish) and plankton (brown algae, cyanobacteria, diatoms). These anoxic conditions occurred in a semi-isolated sea inhabited by endemic biota (Olszewska, 1984; Kotlarczyk and Uchman, 2012; Studencka et al., 2016; Fig. 5B).

The supplies of organic carbon, iron, phosphorus and sulphur favoured the formation of siderites, phosphates and silica. This process was associated with intense oxygen and calcium consumption and contributed to anoxia and acidification. These phenomena coincided with both the bloom of siliceous phytoplankton (radiolarians and diatoms) and perturbations in calcareous zooplankton (foraminifers). Radiolarians were dispersed by turbidity currents in the Paleocene and accumulated by suspension in the Early Eocene, while diatoms became numerous during the hemipelagic deposition in the Late Paleocene and Early Oligocene. These biotic events reflecting eutrophic conditions usually coincided with a decrease in the size and diversity of opportunistic planktic foraminifera.

\section{CONCLUSIONS}

With respect to the geochemical index the Paleogene foraminifera reflect environmental perturbations in the various stages due to the nature of depositional settings and palaeogeographic position of the studied basin. In this area, located in the northern Tethys, habitats were closely controlled by a turbidity system stimulated by diastrophic and geodynamic processes. These factors influenced the structure, evolution and distribution of biotopes, and diagenetic and fossilization processes. Microfossils, especially calcareous forms are poorly preserved or mineralized under unfavourable conditions. Accumulation of organic matter was a consequence of stagnant bottom water conditions in the basin. Its decomposition, intensified by hydrothermal and diagenetic processes, lead to periodic anoxia and acidification in the waters stratified due to temperature and density differences.

Stress associated with rapidly changing oxygen conditions induced by sedimentary processes and upwelling resulted in the dominance of opportunistic benthos and plankton. At that time, agglutinated and some calcareous forms were limited to eutrophic assemblages dominated by individual species representing surficial epifauna and semi-infauna (Glomospira, Ammodiscus, Recurvoides and Rzehakina) and planktic shallow-marine dwellers (Guembelitria, Chiloguembelina, Globanomalina, Globigerina, Cassigerinella and Catapsydrax), or they were replaced by phytoplankton (cyanobacteria, algae, radiolarians and diatoms). The results discussed with respect to geochemical data confirm the impact of environmental stress on the marine life in the Paleogene basin and its relationship with global events (KTBE, PTME, EEOC and TTE). Periods of abrupt changes in temperature, oxygen content, and water circulation that resulted in the formation of siderite, phosphates and silica occurred occasionally under conditions of warm and humid climate during the Paleocene-Eocene. Siliceous minerals and hydrocarbon compounds became dominant during the Oligocene cooling, which was interrupted by warming episodes at the end of this interval.

Acknowledgements. We thank $M$. Kaminski and other anonymous reviewers for their constructive comments on the manuscript. We are grateful to L. Jankowski, R. Kopciowski, T. Malata, P. Nescieruk (Carpathian Branch of the Polish Geological Institute - National Research Institute) and P. Strzeboński (AGH University of Science and Technology) for their help during field work and collection of some samples. The research was financially supported by the PGI-NRI statutory funds. 


\section{REFERENCES}

Alegret, L., Thomas, E., 2009. Food supply to the seafloor in the Pacific Ocean after the Cretaceous/Paleogene boundary event. Marine Micropaleontology, 73: 105-116.

Alegret, L., Thomas, E., 2013. Benthic foraminifera across the Cretaceous/Paleogene boundary in the Southern Ocean (ODP Site $690)$. Diversity, food and carbonate saturation. Marine Micropaleontology, 105: 40-51.

Alegret, L., Thomas, E., Lohmann, K.C., 2012. End-Cretaceous marine mass extinction not caused by productivity collapse. Proceedings of the National Academy of Science, 109: 728-732.

Alve, E., Murray, J.W., Skei, J., 2011. Deep-sea benthic foraminifera, carbonate dissolution and species diversity in Hardangerfjord, Norway: an initial assessment. Estuarine, Coastal and Shelf Science, 92: 90-102

Arreguín-Rodríguez, G.J., Alegret, L., Ortiz, S., 2013. Glomospira acme during the Paleocene-Eocene Thermal Maximum: response to $\mathrm{CaCO}_{3}$ dissolution or to ecological forces? Journal of Foraminiferal Research, 43: 37-49.

Aubry, M.-P., Berggren, W.A., Kent, D.V., Flynn, J.J., Klitgord, K.D., Obradovich, J.D., Prothero, D.R., 1988. Paleogene geochronology: an integrated approach. Paleoceanography, 3: 707-742.

Bains, S., Norris, R.D., Corfield, R.M., Faul, K.L., 2000. Termination of global warmth at the Palaeocene/Eocene boundary through productivity feedback. Nature, 407: 171-173.

Barron, J.A., Baldauf, J.G., 1989. Tertiary cooling steps and paleoproductivity as reflected by diatoms and biosiliceous sediments. In: Productivity of the Ocean: Present and Past, Dahlem Workshop Repts (eds. W.H. Berger, V.S. Smetacek and G. Wefer): 341-354. Wiley, New York.

Barwicz-Piskorz, W., Rajchel, J., 2012. Radiolarian and agglutinated foraminiferal biostratigraphy of the Paleogene deep-water deposits on the northern margin of the Carpathian Tethys (Skole Unit). Geological Quarterly, 56 (1): 1-24.

Bak, M., Barwicz-Piskorz, W., 2006. Multivariate discrimination of Buryella species from the Lower Eocene of the Outher Flysch Carpathians, Poland. Journal of Micropalaeontology, 25: 45-54.

Bąk, K., Bąk, M., Geroch, S., Manecki, M., 1997. Biostratigraphy and paleoenvironmental analysis of benthic foraminifera and radiolarians in Paleogene variegated shales in the Skole unit, Polish Flysch Carpathians. Annales Societatis Geologorum Poloniae, 67: 135-154.

Berger, W.H., 1972. Deep sea carbonates: dissolution facies and age-depth constancy. Nature, 236: 392-395.

Berggren, W.A., Kent, D.V., Flynn, J.J., 1985. Paleogene geochronology and chronostratigraphy. Geological Society Memoir, 10: 141-195.

Berner, R.A., 1984. Sedimentary pyrite formation: an update. Geochimica et Cosmochimica Acta, 48: 605-617.

Bernhard, J.M., 1986. Characteristic assemblages and morphologies of benthic foraminifera from anoxic, organic-rich deposits: Jurassic through Holocene. Journal of Foraminiferal Research, 16: 207-215

Bieńkowska-Wasiluk, M., 2010. Taphonomy of Oligocene teleost fishes from the Outer Carpathians of Poland. Acta Geologica Polonica, 60: 479-533.

Boersma, A., 1986. Eocene/Oligocene Atlantic paleooceanography using benthic foraminifera. In: Terminal Eocene Events (eds. Ch. Pomerol and I. Premoli-Silva): 225-236. Elsevier, Amsterdam.

Bohaty, S.M., Zachos, J.C., 2003. A significant Southern Ocean warming event in the late middle Eocene. Geology, 31: 1017-1020.

Boltovskoy, D., Kogan, M., Alder, W.A., Mianzan, H., 2003. First record of a brackish radiolarian (Polycystina): Lophophaena rioplatensis $\mathrm{n}$. $\mathrm{sp}$. in the Río de la Plata estuary. Journal of Plankton Research, 25: 1551-1559.

Calvert, S.E., Pederson, T.F., 1992. Organic carbon accumulation and preservation in marine sediments: how important is anoxia?
In: Organic Matter: Productivity, Accumulation, and Preservation in Recent and Ancient Sediments (eds. J. Whelan and W. Farrington): 231-263. Columbia University Press.

Cieszkowski, M., 2001. Fore-Magura Zone of the Outer Carpathians in Poland. Biuletyn Państwowego Instytutu Geologicznego, 396: 32-33.

Compton, J.S., Mallinson, D.J., Glenn, C.R., Filippelli, G., Follmi, K., Shields, G., Zanin, Y., 2000. Variations in the global phosphorus cycle. SEPM Special Publication, 66: 21-33.

Corliss, B.H., 1985. Microhabitats of benthic foraminifera within deep-sea sediments. Nature, 314: 435-438.

Corliss, B.H., 1991. Morphology and microhabitat preferences of benthic foraminifera from the northwest Atlantic Ocean. Marine Micropaleontology, 17: 195-236.

Corliss, B.H., Chen, C., 1988. Morphotype patterns of Norwegian Sea deep-sea benthic foraminifera and ecological implications. Geology, 16: 716-719.

De Stigter, H.C., Jorissen, F.J., van der Zwaan, G.J., 1998 Bathymetric distribution and microhabitat partitioning of live (Rose Bengal stained) benthic foraminifera along a shelf to bathyal transect in the southern Adriatic Sea. Journal of Foraminiferal Research, 28: 40-65.

De Wever, P., O’Dogherthy, L., Caridroit, M., Dumitrica, P., Geux, J., Nigrini, C., Caulet, J.-P., 2003. Diversity of radiolarian families through time. Bulletin de la Société Géologique de France, 174: 453-469.

Dimichele, W.A., Phillips, T.L., Olmstead, R.G., 1987. Opportunistic evolution: abiotic environmental stress and the fossil record of plants. Review of Palaeobotany and Palynology, 50: 151-178.

Dziadzio, P., Matyasik, I., Garecka, M., Szydło, A., 2016. Lower Oligocene Menilite Beds, Polish Outer Carpathians: supposed deep-sea flysch locally reinterpreted as shelfal, based on new sedimentological, micropalaeontological and organic-geochemical data. Prace Instytutu Nafty i Gazu, 213: 1-120

Dziubińska, B., Narebski, W., 2004. Siderite concretions in Paleocene series of Polish part of the Eastern Flysch Carpathians. Mineralogia Polonica, 35: 79-91.

Erbacher, J., Hemleben, Ch., Huber, B.T., Markey, M., 1999. Correlating environmental changes during early Albian oceanic anoxic event $1 \mathrm{~B}$ using benthic foraminiferal paleoecology. Marine Micropaleontology, 38: 7-28.

Franus, W., Rajchel, J., 2002. Tuffites from the Variegated Shale Formation of the Skole Unit. Geologica Carpathica (CD book), 56: $1-5$.

Frezza, V., Bergamin, L., Di Bella, L., 2005. Opportunistic benthic foraminifera as indicators of eutrophicated environments. Actualistic study and comparison with the Santernian middle Tiber Valley (Central Italy). Bollettino della Società Paleontologica Italiana, 44: 193-201.

Fontanier, C., Jorissen, F., Geslin, E., Zaragosi, S., Duchemin, G., Laversin, M., Gaultier, M., 2007. Live and dead foraminiferal faunas from Saint-Tropez Canyon (Bay of Fréjus): observations based on in situ and incubated cores. Journal of Foraminiferal Research, 38: 137-156.

Galeotti, S., Kaminski, M.A., Coccioni, R., Speijer, R.P., 2004 High-resolution deep-water agglutinated foraminiferal record across the Paleocene/Eocene transition in the Contessa Road Section (Central Italy). Grzybowski Foundation Special Publication, 8: 83-103

Garecka, M., 2012. Record of changes in the Oligocene-Miocene sediments of the Menilite-Krosno series of the Skole unit based on calcareous nannoplankton studies - biostratigraphy and palaeogeographical implications (Polish Outer Carpathians). Biuletyn Państwowego Instytutu Geologicznego, 453: 1-22.

Gasiński, M.A., 1978. Hantkenina (Foraminiferida) in the Eocene at Bujaków (Polish Carpathians). Annales Societatis Geologorum Poloniae, 48: 39-53.

Gasiński, M.A., Uchman, A., 2011. The Cretaceous-Paleogene boundary in turbiditic deposits identified to the bed: a case study 
from the Skole Nappe (Outer Carpathians, southern Poland). Geologica Carpathica, 62: 333-343.

Geroch, S., Koszarski, L., 1988. Agglutinated foraminiferal stratigraphy of the Silesian flysch through. Abhandlungen der Geologischen Bundesanstalt, 41: 73-79.

Geroch, S., Nowak, W., 1984. Proposal of zonation for the Late Tithonian-Late Eocene, based upon arenaceous Foraminifera from the Outer Carpathians, Poland. In: Bentos'83; 2nd International Symposium on Benthic Foraminifera (Pau, April 11-15/4/1983) (ed. H.J. Oertli): 225-239. Elf Aquitaine, Esso REP et Total CFP.

Geroch, S., Jednorowska, A., Książkiewicz, M., Liszkowa, J., 1967. Stratigraphy based upon microfauna in the Western Polish Carpathians. Biuletyn Instytutu Geologicznego, 211: 185-267.

Golonka, J., Oszczypko, N., Ślączka, A., 2000. Late Carboniferous-Neogene geodynamic evolution and paleogeography of the circum-Carpathian region and adjacent areas. Annales Societatis Geologorum Poloniae, 70: 107-136.

Gooday, A.J., 1990. Recent deep-sea agglutinated foraminifera: a brief review. In: Palaeoecology, Biostratigraphy, Paleooceanography and Taxonomy of Agglutinated Foraminifera (eds. C. Hemleben et al.): 271-304. Kluwer Academic Publishers.

Gradstein, F.M., Berggren, W.A., 1981. Flysch-type agglutinated Foraminifera and the Maestrichtian to Paleogene history of the Labrador and North Seas. Marine Micropaleontology, 6: 211-268.

Gucwa, I., 1990. Studies on the geochemical correlation of sedimentary rocks in the Polish Flysch Carpathians (in Polish with English summary). Prace Państwowego Instytutu Geologicznego, 128: 1-58.

Gucwa, I., Poprawa, D., 1996. Dystrybucja mikroelementów i bituminów w skałach fliszowych polskiej części Karpat (in Polish). Przeglad Geologiczny, 44: 502-508.

Gucwa, I., Ślączka, A., 1980. Trace elements and the growth of phytoplankton in geosynclinal deposits: Oligocene of the Polish flysch Carpathians Proceedings of the XI Congress Carpatho-Balkanian Geological Association, Lithology: 76-82. Kiev.

Gucwa, I., Wieser, T., 1977. Charakterystyka petrograficzno-geochemiczna osadów Karpat fliszowych macierzystych dla bituminów (in Polish). National Geological Archive, PGI-NGI, Kraków.

Gucwa, I., Wieser, T., 1980. Geochemistry and mineralogy of sedimentary rocks of the Carpathian Flysch rich in an organic matter (in Polish with English summary). Prace Mineralogiczne, 69: 7-38.

Giusberti, L., Rio, D., Agnini, C., Backman, J., Fornaciari, E., Tateo, E., Oddone, M., 2007. Mode and tempo of the Paleocene-Eocene thermal maximum in an expanded section from the Venetian pre-Alps. GSA America Bulletin, 119: 391-412.

Haig, D., 1979. Global distribution patterns for Mid-Cretaceous foraminiferids. Journal of Foraminiferal Research, 9: 29-40.

Haq, B.U., Hardenbol, J., Vail, P.R., 1987. Chronology of fluctuating sea levels since the Triassic. Science, 235: 1156-1167.

Haq, B.U., Hardenbol, J., Vail, P.R., 1988. Mesozoic and Cenozoic chronostratigraphy and cycles of sea-level change. SEPM Special Publication, 42: 71-101.

Heinz, P., Kitazato, H., Schmiedl, G., Hemleben, Ch., 2001. Response of deep-sea benthic foraminifera from the Mediterranean Sea to simulated phytoplankton pulses under laboratory conditions. Journal Foraminiferal Research, 31: 210-227.

Hess, S., Jorissen, F.J., 2009. Distribution patterns of living benthic foraminifera from Cap Breton Canyon, Bay of Biscay: faunal response to sediment instability. Deep-Sea Research I, 56: $1555-1578$.

Huss, F., 1957. Stratigraphy of the Węglówka Unit based on microfauna (in Polish with English summary). Acta Geologica Polonica, 7: 29-69.

Jankowski L., 2015. Nowe spojrzenie na budowę geologiczna Karpat - ujęcie dyskusyjne (in Polish). Prace Naukowe Instytutu Nafty i Gazu, 202: 1-154.

Jardine, P., 2011. The Paleocene-Eocene thermal maximum. Palaeontology Online, 1: 1-7.
Jednorowska, A., 1975. Small foraminiferal assemblages in the Paleocene of the Polish Western Carpathians (in Polish with English summary). Studia Geologica Polonica, 47: 3-103.

Jones, R.W., Charnock, M.A., 1985. "Morphogroups" of agglutinated Foraminifera. Their life positions and feeding habits and potential applicability in (paleo)ecological studies. Revue de Paléobiology, 4: 311-320.

Jorissen, F.J., De Stigter, H.C., Widmark, J.G.V., 1995. A conceptual model explaining benthic foraminiferal microhabitats. Marine Micropaleontology, 22: 3-15.

Jurkiewicz, H., 1967. Foraminifers in the Sub-Menilitic Palaeogene of the Polish Middle Carpathians. Biuletyn Instytutu Geologicznego, 210: 5-128.

Kaiho, K., 1994. Benthic foraminiferal dissolved-oxygen index and dissolved-oxygen levels in the modern ocean. Geology, 22: 719-722.

Kaminski, M.A., 1984. Shape variation in Spiroplectammina spectabilis (Grzybowski). Acta Palaeontologica Polonica, 29: 29-46.

Kaminski, M.A., 2005. The utility of deep-water agglutinated foraminiferal acmes for correlating Eocene to Oligocene abyssal sediments in the North Atlantic and Western Tethys. Studia Geologica Polonica, 124: 325-339.

Kaminski, M.A., 2012. Calibration of the Benthic Foraminiferal Oxygen Index in the Marmara Sea. Geological Quarterly, 56 (4): 757-764.

Kaminski, M.A., Kuhnt, W., 1995. Tubular agglutinated foraminifera as indicators of organic carbon flux. Grzybowski Foundation Special Publication, 3:141-144.

Kaminski, M.A., Boersma, A., Tyszka, J., Holbourn, A., 1995. Response of deep-water agglutinated foraminifera to dysoxic conditions in the California borderland basins. Grzybowski Foundation, 3: 131-140.

Kaminski, M.A., Kuhnt, W., Moullade, M., 1999. The evolution and paleobiogeography of abyssal agglutinated foraminifera since the Early Cretaceous: a tale of four faunas. Neues Jahrbuch für Geologie und Paläontologie Abhandlungen, 212: 401-439.

Katz, M.E., Cramer, B.S., Mountain, G.S., Katz, S., Miller, K.G., 2001. Uncorking the bottle: What triggered the Paleocene/Eocene thermal maximum methane release? Paleoceanography, 16: $549-562$.

Keller, G., 1989. Extended period of extinctions across the Cretaceous-Tertiary boundary in planktonic foraminifera of continental shelf sections: implications for impact and volcanism theories. GSA Bulletin, 101: 1408-1419.

Keller, G., Benjamini, C., 1991. Paleoenvironment of the eastern Tethys in the early Paleocene. Palaios, 6: 439-464.

Keller, G., Pardo, A., 2004. Disaster opportunists Guembelitrinidae: index for environmental catastrophes. Marine Micropaleontology, 53: 83-116.

Kelly, D.C., 2002. Response of Antarctic (ODP Site 690) planktonic foraminifera to the Paleocene-Eocene thermal maximum: faunal evidence for ocean/climate change. Paleoceanography, 17: 1071.

Kelly, D.C., Bralower, T.J., Zachos, J.C., 1998. Evolutionary consequences of the latest Paleocene thermal maximum for tropical planktonic foraminifera. Palaeogeography, Palaeoclimatology, Palaeoecology, 141: 139-161.

Kennett, J.P., Stott, L.D., 1991. Abrupt deep-sea warming, palaeoceanographic changes and benthic extinctions at the end of the Palaeocene. Nature, 353: 225-229.

Köster, J., Rospondek, M., Schouten, S., Kotarba, M., Zubrzycki, A., Sinninghe Damsté, J.S., 1998. Biomarker geochemistry of a foreland basin: the Oligocene Menilite Formation in the Flysch Carpathians of Southeast Poland. Organic Geochemistry, 29: 649-669.

Koszarski, L., Sikora, W., Wdowiarz, S., 1974. The flysch Carpathians. Polish Carpathians. In: Tectonics of the Carpathian-Balkan Region (ed. M. Mahel): 180-197. Geologicky Ustav Dionyza Stura.

Kotlarczyk, J., Uchman, A., 2012. Integrated ichnological and ichthyological analysis of oxygenation changes in the Menilite Formation during Oligocene, Skole and Subsilesian nappes, 
Polish Carpathians. Palaeogeography, Palaeoclimatology, Palaeoecology, 331-332: 104-118.

Książkiewicz, M., 1961. Life conditions in flysch basins. Rocznik Polskiego Towarzystwa Geologicznego, 31: 3-21.

Książkiewicz, M. ed., 1962. Geological Atlas of Poland; Stratigraphic and Facial Problems 13. Cretaceous and Older Paleogene in the Polish Outer Carpathians. Wyd. Geol., Warszawa.

Ksiażkiewicz, M., 1975. Bathymetry of the Carpathians Flysch Basin. Acta Geologica Polonica, 25: 309-367.

Kuhnt, W., Geroch, S., Kaminski, M.A., Moullade, M., Neagu, T., 1992. Upper Cretaceous abyssal claystones in the North Atlantic and Western Tethys: current status of biostratigraphical correlation using agglutinated foraminifera and paleogeographic events. Cretaceous Research, 13: 467-478.

Kuhnt, W., Moullade, M., Kaminski, M.A., 1996. Ecological structuring and evolution of deep sea agglutinated foraminifera $-\mathrm{a}$ review. Revue de Micropaleontologie, 39: 271-281.

Lange, B.M., Rujan, T., Martin, W., Croteau, R., 2000. Isoprenoid biosynthesis: the evolution of two ancient and distinct pathways across genomes. Proceedings of the National Academy of Sciences USA, 97: 13172-13177.

Lee, H.J., Locat, J., Desgagnés, P., Parsons, J.D., McAdoo, B.G., Orange, D.L., Puig, P., Wong, F.L., Dartnell, P., Boulanger, E., 2007. Submarine mass movements on continental margins. IAS Special Publication, 37: 213-274.

Leszczyński, S., Kołodziej, B., Bassi, D., Malata, E., Gasiński, M.A., 2012. Origin and resedimentation of rhodoliths in the Late Paleocene flysch of the Polish Outer Carpathians. Facies, 58: 367-38.

Leśniak, T., Waśkowska-Oliwa, A., Cieszkowski, M., 2001. Siliciclastic deposits (Palaeogene) of the Subsilesian Unit in the Żywiec area. Zeszyty Naukowe AGH - Geologia, 27: 51-70.

Levinton, J.S., 1970. The paleoecological significance of opportunistic species. Lethaia, 3: 69-78.

Loubere, P., 1989. Bioturbation and sedimentation rate control of benthic microfossils taxon abundances in surface sediments: a theoretical approach to the analysis of species microhabitats. Marine Micropaleontology, 14: 317-325.

Luciani, V., Dickens, G.R., Backman, J., Fornaciari, E., Giusberti, L., Agnini, C., D'Onofrio, R., 2016. Major perturbations in the global carbon cycle and photosymbiont-bearing planktic foraminifera during the early Eocene. Climate Past, 12: 981-1007.

MacLeod, N., 1993. The Maastrichtian-Danian radiation of tri serial and biserial planktic foraminifera: Testing phylogenetic and adaptational hypotheses in the (micro) fossil record. Marine Micropaleontology, 21: 47-100.

Malata, T., 1996. Analysis of standard lithostratigraphic nomenclature and proposal of division for Skole unit in the Polish Flysch Carpathians. Geological Quarterly, 40: 543-554.

Melinte-Dobrinescu, M.C., Roban, R.-D., 2011. Cretaceous anoxic-oxic changes in the Moldavids (Carpathians, Romania). Sedimentary Geology, 235: 79-90.

Miller, K.G., Fairbanks, R.G., Mountain, G.S., 1987. Tertiary oxygen isotope synthesis, sea-level history and continental margin erosion. Paleoceanography, 2: 1-19.

Miller, A.W., Reynolds, A.C., Sobrino, C., Riedel, G.F., 2009 Shellfish Face Uncertain Future in High $\mathrm{CO}_{2}$ World: Influence of Acidification on Oyster Larvae Calcification and Growth in Estuaries. PLoS ONE 4: e5661.

Morgiel, J., Olszewska, B., 1981. Biostratigraphy of the Polish External Crapathians based on agglutinated foraminifera. Micropaleontology, 27: 1-30

Morgiel, J., Szymakowska, F., 1978. Stratygrafia paleocenu i eocenu jednostki skolskiej. Biuletyn Instytutu Geologicznego, 310: $39-71$

Muszyński, M., Rajchel, J., Salamon, W., 1979. Concretionary iron and manganese carbonates in Eocene shales of the environs of
Dynów near Przemyśl (Flysch Carpathians). Mineralia Polonica, 9: 111-121.

Nagy, J., Gradstein, F.M., Kaminski, M.A., Holbourn, A.E., 1995 Foraminiferal morphogroups, paleoenvironments and new taxa from Jurassic to Cretaceous strata of Thakkhola, Nepal. Grzybowski Foundation Special Publication, 3: 181-209.

Nagy, J., Reolid, M., Rodríguez-Tovar, F.J., 2009. Foraminiferal morphogroups in dysoxic shelf deposits from the Jurassic of Spitsbergen. Polar Research, 28: 214-221.

Nescieruk, P., Szydło, A., 2003. Rozwój i pozycja stratygraficzna warstw istebniańskich w Beskidzie Morawsko-Ślaskim (in Polish). Sborník Vedeckých Prací Vysoké Školy Báňské, 49: 74-75.

Nowak, W., 1954. About stratigraphic significance of genus Hantkenina (in Polish with English summary). Przegląd Geologiczny, 2: 377-380.

Olszewska, B., 1973. Some upper Eocene foraminifer assemblages from the central part of Dukla Unit in the Carpathian (in Polish with English summary). Geological Quarterly, 17 (3): 529-538.

Olszewska, B., 1980. Foraminiferal stratigraphy of the Upper Cretaceous and Paleogene sediments of the central part of the Dukla Unit (in Polish with English summary). Biuletyn Instytutu Geologicznego, 326: 59-97.

Olszewska, B., 1984. A paleoecological interpretation of the Cretaceous and Paleogene foraminifers of the Polish Outer Carpathians. Biuletyn Instytutu Geologicznego, 346: 7-53.

Olszewska, B., 1985. Foraminifera from the Menilite beds of Polish Outer Carpathians (in Polish with English summary). Annales Societatis Geologorum Poloniae, 55: 201-250.

Olszewska, B., 1997a. Foraminiferal biostratigraphy of the Polish Outer Carpathians: a record of basin geohistory. Annales Societatis Geologorum Poloniae, 67: 325-337.

Olszewska, B., 1997b. Biofacies of the Polish Carpathians (in Polish). National Geological Archive, PIG (no. 876314).

Olszewska, B., Malata, E., 2006. Paleoenvironmental and paleobatymetrical analysis of microfossil assemblages of the Polish Outer Carpathians. In: Paleotectonic Evolution of the Outer Carpathian and Pieniny Klippen Basins (eds. N. Oszczypko, A. Uchman and E. Malata): 64-68. Instytut Nauk Geologicznych Uniwersytet Jagielloński.

Olszewska, B., Odrzywolska-Bieńkowa, E., Giel, M.D., Pożaryska, K., Szczechura, J., 1996. Rząd Foraminiferida (in Polish). In: Atlas skamieniałości przewodnich i charakterystycznych: t. III, cz. 3a, Paleogen (eds. L. Malinowska and M. Piwocki): 45-216. Polska Agencja Ekologiczna.

Oszczypko, N., 2004. The structural position and tectonosedimentary evolution of the Polish Outer Carpathians. Przeglad Geologiczny, 52: 780-791.

Oszczypko, N., 2006. Late Jurassic-Miocene evolution of the Outer Carpathian fold-and-thrust belt and its foredeep basin (Western Carpathians, Poland). Geological Quarterly, 50 (1): 169-194.

Pekar, S.F., DeConto, R.M., Harwood, D.M., 2006. Resolving a late Oligocene conundrum: deep-sea warming and Antarctic glaciation. Palaeogeography, Palaeoclimatology, Palaeoecology, 231: $29-40$

Pérez, M.E., Charles, C.D., Berger, W.H., 2001. Late Quaternary productivity fluctuations off Angola: evidence from benthic foraminifers, Site 1079. Proceedings of the Ocean Deep Projects. Scientific Results, 175: 1-19.

Praetorius, S.K., Mix, A.C., Walczak, M.H., Wolhowe, M.D., Addison, J.A., Prahl, F.G., 2015. North Pacific deglacial hypoxic events linked to abrupt ocean warming. Nature, 527: 362-366.

Röhl, U., Westerhold, T., Monechi, S., Thomas, E., Zachos, J. C., Donner, B., 2005. The Third and Final Early Eocene Thermal Maximum: Characteristics, Timing and Mechanisms of the ' $X$ ' Event, GSA Annual Meeting 37, Geological Society of America, Salt Lake City, USA.

Salata, D., Uchman, A., 2012. Heavy minerals from Oligocene sandstones of the Menilite Formation of the Skole Nappe, SE 
Poland: a tool for provenance specifiction. Geological Quarterly, 56 (4): 803-812.

Salata, D., Uchman, A., 2013. Conventional and high-resolution heavy mineral analyses applied to flysch deposits: comparative provenance studies of the Ropianka (Upper Cretaceous-Paleocene) and Menilite (Oligocene) formations (Skole Nappe, Polish Carpathians). Geological Quarterly, 57 (4): 649-664.

Speijer, R.P., Schmitz, B., van der Zwaan, G.J., 1997. Benthic foraminiferal extinction and repopulation in response to latest Paleocene Tethyan anoxia. Geology, 250: 683-686.

Spezzaferri, S., Premoli Silva, I., 1991. Oligocene planktonic foraminiferal biostratigraphy and paleoclimatic interpretation from Hole 538A, DSDP Leg 77, Gulf of Mexico. Palaeogeography, Palaeoclimatology, Palaeoecology, 83: 217-263.

Spezzaferri, S., Spiegler, D., 2005. Fossil planktic foraminifera (an overview). Paläontologische Zeitschrift, 79: 149-166.

Stott, L.D., 1992. Higher temperatures and lower oceanic $\mathrm{PCO}_{2}$ : a climate enigma at the end of the Paleocene epoch. Paleoceanography, 7: 395-404.

Strzeboński, P., 2015. Late Cretaceous-Early Palaeogene sandy-to-gravelly debris flows and their sediments in the Silesian Basin of the Alpine Tethys (Western Outer Carpathians, Istebna Formation). Geological Quarterly, 59 (1): 195-214.

Studencka, B., Popov, S.V., Bieńkowska-Wasiluk, M., Wasiluk, R., 2016. Oligocene bivalve faunas from the Silesian Nappe, Polish Outer Carpathians: Evidence for the early history of the Paratethys. Geological Quarterly, 60 (2): 317-340.

Szydło, A., Olszewska, B., 2012. Dark deposits of the Polish Outher Carpathians: implications for anoxic events in the Tethys on the basis of micropalaeontological data (Cretaceous-Paleogene). In: 2nd International Conference "Alpine-Petrol" (eds. M.J. Kotarba and M. Wróbel): 91-92. Book of Programme and Abstracts, Kraków, 2012.

Szydło, A., Garecka, M., Jankowski, L., Malata, T., 2014. Paleogene microfossils from the submarine derbis flows in the Skole basin (Polish and Ukraine Outer Carpathians). Geology, Geophysics and Environments, 40: 49-65.

Szydło, A., Jugowiec-Nazarkiewicz, M., Słodkowska, B., 2015a. Response of micro- and nannofossils to facies changes in the Silesian Basin from the Campanian to Paleocene (Silesian-Subsilesian zone, Polish Outer Carpathians). Grzybowski Foundation Special Publication, 21: 76-77.

Szydło, A., Słodkowska, B., Nescieruk, P., Strzeboński, P., 2015b. Microfossils from the Istebna beds: implications for stratigraphy and depositional environment. Grzybowski Foundation Special Publication, 21: 74-75.

Ślączka, A., Kaminski, M.A., 1998. A guidebook to excursions in the Polish Flysch Carpathians. Grzybowski Foundation Special Publication, 6: 1-177.

Ślączka, A., Golonka, J., Oszczypko, N., Cieszkowski, M., Słomka, T., Matyasik, I., 2014. Occurrence of the Upper Jurassic-Lower Cretaceous black organic-rich pelitic sediments as targets for unconventional hydrocarbon exploration in the Outer Carpathians and adjacent part of Alps. AAPG Bulletin, 98:1967-1994.

Taucher, J., Schulz, K.G., Dittmar, T., Sommer, U., Oschlies, A., Riebesell, U., 2012. Enhanced carbon overconsumption in response to increasing temperatures during a mesocosm experiment. Biogeosciences 9: 3531-3545.

ten Haven, H. L., Lafargue, E., Kotarba, M., 1993. Oil/oil and oil/source rock correlations in the Carpathian Foredeep and overthrust, south-east Poland. Organic Geochemistry 20: 935-959.

Thomas, E., Brinkhuis, H., Huber, M., Röhl, U., 2006. An ocean view of the early Cenozoic Greenhouse World. Oceanography, 19: $63-72$.

Tucker, M., 1991. Sedimentary Petrology: an Introduction to the Origin of Sedimentary Rocks. Blackwell Science.
Waśkowska, A., 2008. The Early Eocene Saccamminoides carpathicus Assemblage in the Outer Flysch Carpathians. Grzybowski Foundation Special Publication, 16: 331-341.

Waśkowska, A., 2014a. The Eocene Hieroglyphic beds and Green shales in the Rożnów Lake area (Silesian Nappe, Outer Carpathians) - facies development and biostratigraphy. Geology, Geophysics and Environments, 40: 5-26.

Waśkowska, A., 2014b. Distribution of the agglutinated foraminifer Ammolagena clavata, Upper Cretaceous and Paleogene, Poland. Micropaleontology, 60: 77-88.

Waśkowska, A., 2015. Eocene Hieroglyphic beds of Silesian Nappe in Western Polish Carpathians - development and foraminiferal record. Geological Quarterly, 59 (2): 271-299.

Waśkowska, A., Cieszkowski, M., Golonka, J., Kowal-Kasprzyk, J., 2014. Paleocene sedimentary record of ridge geodynamics in Outer Carpathian basins (Subsilesian Unit). Geologica Carpathica, 65: 35-54.

Waśkowska-Oliwa, A., 2005. Foraminiferal paleodepth indicators from the lower Palaeogene deposris of the Subsilesian Unit (Polish Outer Carpathians). Studia Geologica Polonica, 124: 297-324.

Waśkowska-Oliwa, A., 2008. The Paleocene assemblages of agglutinated foraminifera from deep-water basin sediments of the Carpathians (Subsilesian Unit, Poland) - biostratigraphical remarks. Grzybowski Foundation Special Publication, 13: 227-265.

Williams, N.L., Juranek, L.W., Feely, R.A., Johnson, K.S., Sarmiento, J.L., Talley, L.D., Dickson, A.G., Gray, A.R., Wanninkhof, R., Russell, J.L., Takeshita, Y., 2017. Calculating surface ocean $\mathrm{pCO}_{2}$ from biogeochemical Argo floats equipped with $\mathrm{pH}$ : an uncertainty analysis. Global Biogeochemical Cycles 31: 591-604.

Vetö, I., 1987. An Oligocene sink for organic carbon: upwelling in the Paratethys? Palaeogeography, Palaeoclimatology, Palaeoecology, 60: 143-153.

Villa, G., Persico, D., 2006. Late Oligocene climatic changes: evidence from calcareous nannofossils at Kerguelen Plateau Site 748 (Southern Ocean). Palaeogeography, Palaeoclimatology, Palaeoecology, 231: 110-119.

Vogt, P.R., 1989. Volcanogenic upwelling of anoxic, nutrient rich water: a possible factor in carbonate-bank/reef demise and benthic faunal extinctions? GSA Bulletin, 101: 1225-1245.

Zachos, J., Pagani, M., Sloan, L., Thomas, E., Billups, K., 2001. Trends, rhythms, and aberrations in global climate $65 \mathrm{Ma}$ to present. Science, 292: 686-693.

Zachos, J.C., Röhl, U., Schellenberg, S.A., Sluijs, A., Hodell, D.A., Kelly, D.C., Thomas, E., Nicolo, M., Raffi, I., Lourens, L.J., McCarren, H., Kroon, D., 2005. Rapid acidification of the ocean during the Paleocene-Eocene thermal maximum. Science, 308: 1611-1615.

Zielińska, M., 2010. Petrographic structure of terrestrial organic matter in Poland's Western Flysch Carpathians (in Polish with English summary). Kwartalnik AGH - Geologia, 4: 567-584.

Zielińska, M., 2017. Organic-matter vitrinite reflectance variability in the Outer Carpathians, Poland: relationship to tectonic evolution. Geological Quarterly, 61 (1): 214-226.

Van der Zwaan, G.J., Duijnstee, I.A.P., den Dulk, M., Ernst, S.R., Jannink, N.T., Kouwenhoven, T.J., 1999. Benthic foraminifers: proxies or problems? A review of palaeoecological concept, Earth-Science Reviews, 46: 213-235.

Żytko, K., Gucik, S., Ryłko, W., Oszczypko, N., Zając, R., Garlicka, I., Nemčok, J., Elias, M., Menčik, E., Dvořák, J., Stránik, Z., Rakus, M., Matějovská, O., 1989. Geological map of the Western Outer Carpathians and their foreland - without Quaternary formations. In: Geological Atlas of the Western Outer Carpathians and their Foreland. 1:500 000 (eds. D. Poprawa and J. Nemčok). Państwowy Instytut Geologiczny, Warszawa. 